\title{
Controlling the structure and morphology of ZnS nanoparticles by manipulating the temperature profile
}

ChAN Gı LEE - AIST - change-ri@aist.go.jp

YusUKE NAKAMURA - Kyushu University - md-y-nakamura@mms.kyushu-u.ac.jp

HIROYUKı NAKAMURA - AIST - nakamura-hiroyuki@aist.go.jp

MASATo UEHARA - AIST - m.uehara@aist.go.jp

HIDEAKI MAEDA - AIST, Kyushu University, CREST - maeda-h@aist.go.jp

Received: 16.02.2011. - Érkezett: 2011.02.16. http://dx.doi.org/10.14382/epitoanyag-jsbcm.2011.9

We propose a method to control the kinetics by controlling the reaction condition stringently with time. One-pot temperature triggered reaction system was employed with identical raw material solutions of ZnS nanoparticles and several patterns of heating profile to show their effects and usefulness during the preparation process were applied. ZnS raw materials were heated up by two type heating rate profile $\left(0.01^{\circ} \mathrm{C} / \mathrm{sec}, 500^{\circ} \mathrm{C} / \mathrm{sec}\right)$ to achieve the desired temperature. In high heating rate $\left(500^{\circ} \mathrm{C} / \mathrm{sec}\right)$, zinc blend (ZB) phase spherical nanoparticles were obtained above $125^{\circ} \mathrm{C}$. Wurtzite (WZ) phase ZnS nanorods were synthesized under a low heating rate condition $\left(0.01^{\circ} \mathrm{C} / \mathrm{sec}\right)$. Furthermore, the crystal phase of the final particles is determined by the initial temperature during particle generation.

Keywords: phase and morphology control, temperature profile, ZnS nanoparticle

\section{Introduction}

Potential applications of nanoparticles are expected for various fields such as electronics, energy, and biology. Generally, the physical and chemical properties of nanoparticles are dependent on the structure (e.g. defects, composite structures, and crystal phases) and morphology (e.g. size and shapes of particles) $[1,2]$. Therefore, structure and morphology control of nanoparticles is an important issue, and many reports on the synthesis of metal and semiconductor nanoparticles have been reported $[1,2]$. Generally for a nanoparticle synthesis by chemical solution process, a reaction condition, which is determined by the type and concentration of each chemical reagents, reaction temperature and time etc., are selected to control the reaction thermodynamics and kinetics. Because the nanoparticle preparation process basically treats a nonequilibrium states, apart from the equilibrium control of reaction, kinetic control of processes such as nucleation, growth, aggregation, and ripening are important [1-3]. The importance of kinetic control is recognized by many researchers, especially for particle size and distribution. Timing and rate of nucleation and growth that is a result of comprehensive growth mechanism that is influenced by surface reaction rate and monomer feeding rate are said to strongly affects the particle size distribution [4-6] and particle shape [1,2]. Moreover, in recent years, some studies revealed the effect of kinetic control on crystal phase, defect generation and doping concentration of nanoparticles [7-16]. Generally, surface energy and volume energy determine the total free energy of nanoparticles. Therefore, the factors to determine those energies (e.x. particle diameter, sort and area of crystal face, adsorption and desorption of capping agents (i.e. surface ligands)) are affected by several kinetics including nucleation and growth kinetics and also by adsorption-desorption kinetics of capping agents. As such, the kinetic control can be a useful factor for colloidal investioate and develop nanocrystal materials. He has investigated the phase stability and morphology of ZnS nanocrystals in recent years.

Prof. Dr. Hideaki MAEDA actually is leader of Micro-Space Chemistry Solution Team, MSRC, National Institute of Advanced Industrial Science and Technology (AIST), Japan, Professor of Kyushu University, and Research Director of CREST, JST. After he received his master degree from Kyushu University in 1989, he worked for Mitsui mining company LTD., Kyushu University and joined AIST from 1999. He has got engineering degree at Kyushu University in 1994. His current research field is microspace chemistry.

nanoparticle synthesis procedure. The full understanding and exploitation of such kinetic effects will help more in controlling the production of nanoparticles, and furthermore, it may help realize a new process, e.g. preparation of various structures and morphologies (i.e. different properties) of nanoparticles from a handful of types of reaction systems. There are two types of methods for kinetic control. One is to control the reaction kinetics by reaction conditions $[5,8,9,11,12,16]$, and the other is to control the reaction conditions stringently with time $[7,10,13,14]$. In the current state, the former is dominant because it is rather difficult to control the reaction condition with time in a quantitative manner; however, it is possible to find some reports for the latter case. For example, Manna et al has reported on kinetic effects on shape of CdSe nanocrystals. They controlled branching and phase of CdSe nanocrystals by "rapid" and "slow" injection of CdSe raw material solution with proper timing [13]. Also, Cozzoli et al. reported phase and shape control of ZnSe nanocrystals except control over ligands. The injection of large volumes of stock solution yielded spherical particles in the exclusive cubic ZB structure, whereas slow, dropwise addition of the same stock solution promoted the formation of rodlike in the WZ phase [10]. However, from the viewpoint of controllability of kinetics, quantitative control of mixing is not easy - a partially high concentration and temperature fluctuations that can be generated during raw material injection may give unwanted effects. Puntes et.al. 
showed that the heating time of the reaction solution can affect the crystal phase of Co [14]. Therefore, in this study, we employed a simple temperature triggered reaction. Here it should be noted that a microreactor, which is a small flow type chemical ractor whose representative size is less than $1 \mathrm{~mm}$, is a very useful tool for precise temperature control with time [17]. The reactor can heat room temperature reaction solution up to reaction temperature (e.g. $200^{\circ} \mathrm{C}$ ) within ca. $0.5 \mathrm{~s}$, in a homogeneous manner [18].

In this study, we tried to control the phase and morphology of $\mathrm{ZnS}$. $\mathrm{ZnS}$ has a wide optical band gap $(3.6 \mathrm{eV})$, and a promising material for novel applications including lightemitting diodes (LEDs), electroluminescence, and sensors, etc. [19]. ZnS have two representative polymorphs, i.e. cubic ZB structure and hexagonal WZ structure. For bulk system, the $\mathrm{ZB}$ at low-temperature phase is more stable while the $\mathrm{WZ}$ at high-temperature form polymorphs at around $1023^{\circ} \mathrm{C}[20]$. However, DFT calculation showed that the phase stability also depends on particle size (diameter) and $\mathrm{WZ}$ phase is more stable than $\mathrm{ZB}$ phase when the particle size was smaller than $4 \mathrm{~nm} \mathrm{[21],} \mathrm{as} \mathrm{the} \mathrm{result} \mathrm{of} \mathrm{high} \mathrm{surface/volume} \mathrm{ratio.}$ Furthermore, several researchers have reported that the composition of ligands and solvents in the reaction solution affect the crystal phase, because these factors influence the surface energy of particles [22-24]. As such, the crystal phase of the $\mathrm{ZnS}$ nanoparticles is considered to be strongly affected by the size and surface energy of nanoparticles. Therefore, the stability of the phase can be affected by the particle size (i.e. surface/volume ratio) and shape (i.e. crystal habit) as the result of growth process (i.e. growth mechanism), and reaction environment around the nanoparticles (i.e. thermodynamical equilibrium including surface state of the particle). Therefore, many researchers report on the phase and shape control of $\mathrm{ZnS}$ nanoparticle by the solution process [23-25].

From this point of view, we selected $\mathrm{ZnS}$ nanoparticles as a model material, and tried to control the crystal phase and morphology by kinetic control. For simplicity, one-pot temperature triggered reaction system was employed with identical raw material solutions, and applied a few patterns of heating profile to show the effects and usefulness of the heating pattern during the preparation process.

\section{Experimental procedure}

Zinc iodide $\left(\mathrm{ZnI}_{2}, 99.999 \%\right)$ and sulfur $(\mathrm{S})$ powder were provided by Aldrich. Oleylamine and 1-octadecene (reagent grade) were purchased from Acros Organic and Wako Pure Chemicals, respectively. All solvents were vacuum distilled before use. ZnS nanocrystals were prepared by a solution process called "organo-metallic route" [26], $\mathrm{ZnI}_{2}$ was dissolved in oleylamine $(0.03 \mathrm{~mol} / \mathrm{L})$ at room temperature, and $S$ powder was dissolved in octadecene at $150^{\circ} \mathrm{C}(0.15 \mathrm{~mol} / \mathrm{L})$. After cooling the solution to room temperature, these solutions were mixed and used as a raw material for $\mathrm{ZnS}$ nanocrystals. $\mathrm{ZnS}$ nanocrystals were synthesized with several pattern temperature profiles. For slow heating rate, the raw material solution for $\mathrm{ZnS}$ was heated in oil bath, immediately after mixing $\mathrm{Zn}$ and S source solution in a glass vessel. The heating rate was controlled using PID (proportional-integral-derivative) controller. For rapid heating, a glass capillary with an internal diameter (ID) of $200 \mu \mathrm{m}$ was used to heat the raw material solution and collected in a glass vessel for further heating. A heat transfer calculation was used based on the expectation that in room temperature the solution can be heated within $0.4 \mathrm{~s}$ up to $200^{\circ} \mathrm{C}$ $\left(500^{\circ} \mathrm{C} / \mathrm{sec}\right)$ for the current type of microreactor [18].

The product nanocrystals were washed with ethanol and redispersed in hexane. ZnS nanocrystals were characterized by X-ray diffraction (XRD, RINT-TTR; Rigaku) and scanning transmission electron microscope (STEM, S-5200; Hitachi High-Technology) to determine the crystal phase and morphologies. In addition, the average particle sizes and rod lengths were calculated by analysis of SEM images (Quick Grain).

\section{Results and discussion}

At first, two heating profiles were applied for $\mathrm{ZnS}$ nanoparticle synthesis: profile A-heating with heat-up from room temperature to $200^{\circ} \mathrm{C}$ by using a heating rate of $0.01{ }^{\circ} \mathrm{C} / \mathrm{s}$ and maintenance at $200^{\circ} \mathrm{C}$ for $1 \mathrm{~h}$, and profile B-heating with an increase in temperature up to $200^{\circ} \mathrm{C}$ by heating rate of $500^{\circ} \mathrm{C} / \mathrm{s}$ and maintenance at $200^{\circ} \mathrm{C}$ for $1 \mathrm{~h}$. In order to observe the development of particle shape and phase, an aliquot of the sample was purified for STEM and XRD analysis. The schematics of applied temperature profile and morphology for each sampling point is shown in Fig. 1. XRD diffraction pattern for each sampling point is shown in Fig. 2. With the low heating rate $\left(0.01{ }^{\circ} \mathrm{C} / \mathrm{sec}\right)$ condition (profile A: Fig. 1.) the product yield (PY) at $100{ }^{\circ} \mathrm{C}$ was $60 \%$ and it reached $\sim 100 \%$ at $125^{\circ} \mathrm{C}$. At $100^{\circ} \mathrm{C}$, the produced particles were very small $(<\sim 2$ $\mathrm{nm}$ ) and the morphology was not clear. However, at $125^{\circ} \mathrm{C}$, the morphology was rather ellipsoidal, whose short axis was about $3 \mathrm{~nm}$ and long axis was $5 \mathrm{~nm}$. With an increase in temperature up to $175^{\circ} \mathrm{C}$, the length of the particle increased to $7 \mathrm{~nm}\left(150^{\circ} \mathrm{C}\right)$ and $8 \mathrm{~nm}\left(175^{\circ} \mathrm{C}\right)$ without showing obvious change in short axis $(3 \mathrm{~nm})$. On the other hand, the crystal phase at $100^{\circ} \mathrm{C}$ was not clear (Fig. 2. (a)), but at $125^{\circ} \mathrm{C}$ the hexagonal WZ structure started to become visible and completely dominated at $175^{\circ} \mathrm{C}$. These results indicate that $\mathrm{ZnS}$ generation by chemical reaction is already completed at $125^{\circ} \mathrm{C}$, and the $\mathrm{c}$ axis of wurtzite (WZ) $\mathrm{ZnS}$ grows with temperature with maintenance of constant width. This result suggests an oriented attachment of WZ ZnS nanoparticles (and rods) wherein they serve as building blocks [27]. On the other hand, from $175^{\circ} \mathrm{C}$ to $200^{\circ} \mathrm{C}$, the growth became isotropic with the short and long axis increasing to 4 $\mathrm{nm}$ and $10 \mathrm{~nm}$, respectively. The following $1 \mathrm{~h}$ aging showed no difference in the average length and width, but based on the STEM image, their size distribution appears to increase by aging. At $200^{\circ} \mathrm{C}$, the $\mathrm{WZ}$ peak became weaker than that $175^{\circ} \mathrm{C}$ and less obvious after $1 \mathrm{~h}$ of aging. The isotropic growth of rod like $\mathrm{ZnS}$ under equilibrium yield implies that the growth is caused by Ostwald ripening. The reason for the change in the growth mechanism is not clear at present but can probably be caused by enhancement of the material transfer rate (i.e. dissolution and re-deposition rate) due to Ostwald ripening. It should be noted that the increase in zinc blende (ZB) phase at $200^{\circ} \mathrm{C}$ might shows that $\mathrm{ZB}$ phase is more preferred at this 
temperature for the current reaction system. In the case of profile $\mathrm{B}$, after the temperature reached $200^{\circ} \mathrm{C}$ within $1 \mathrm{~s}$, the product yield increased with aging time; $15 \%$ (5 s), 40\% (10 s), $60 \%$ (20 s) and $85 \%$ (60 s). The morphology of the particles were hardly observable by STEM before $10 \mathrm{~s}$, but at $20 \mathrm{~s}$ (PY 60\%), small isotropic particles of $\sim 2 \mathrm{~nm}$ in diameter were observed, and characterized as ZB structure by XRD. Further aging made the particles grow to $3.5 \mathrm{~nm}(10 \mathrm{~min})$ and $4.0 \mathrm{~nm}(60 \mathrm{~min})$ without any change in isotropic morphology and crystal phase (ZB) under an equilibrium product yield. The crystal phase for the high heating rate (profile $\mathrm{B}$ ) was $\mathrm{ZB}$ from the early stage and was different in comparison to the $\mathrm{WZ}$ observed for the low heating rate (profile $\mathrm{A}$ ). This result agrees with the former results which indicate higher stability of $\mathrm{ZB}$ at $200^{\circ} \mathrm{C}$.

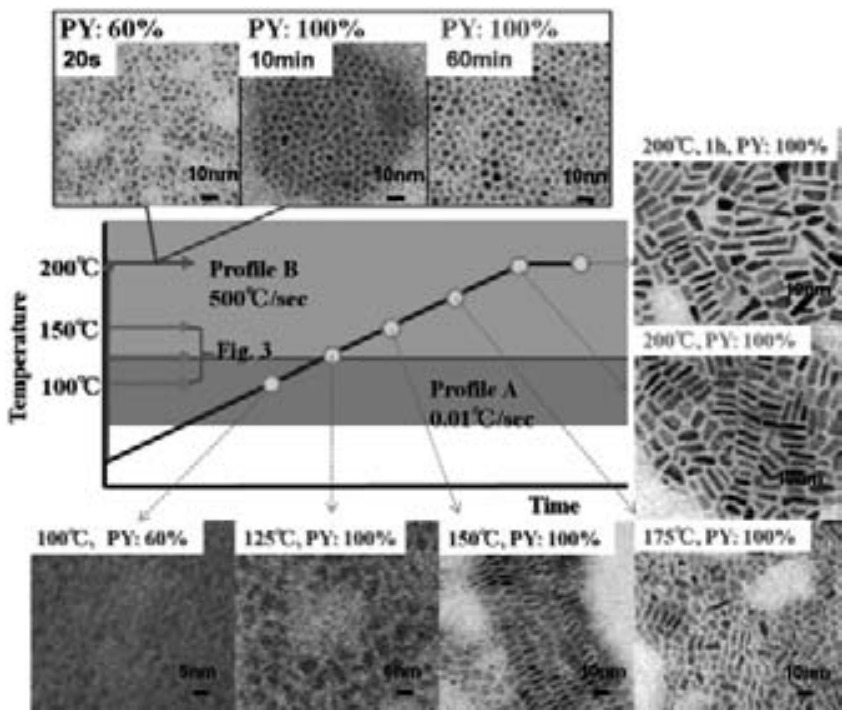

Fig. 1. Schematic diagram of temperature profile and SEM images of $\mathrm{ZnS}$ nanoparticles

1. ábra A hömérsékletprofil és a ZnS nanorészecskék pásztázó elektronmikroszkópos (SEM) felvétele
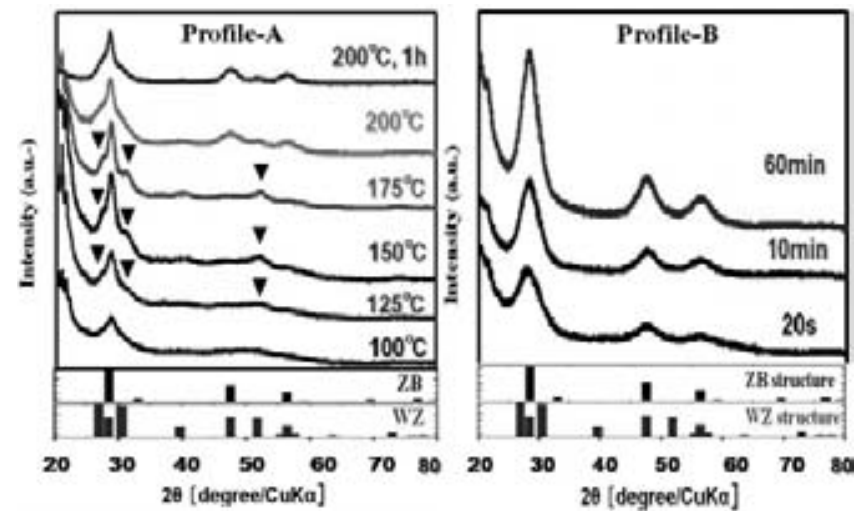

Fig. 2. Typical XRD pattern of $\mathrm{ZnS}$ nanoparticles; (a) high heating rate $\left(500^{\circ} \mathrm{C} / \mathrm{sec}\right)$, (b) low heating rate $\left(0.01^{\circ} \mathrm{C} / \mathrm{sec}\right)$.

2. ábra ZnS nanorészecskék jellemzö röntgen-diffraktogramjai (a) fütési sebesség $500^{\circ} \mathrm{C} / \mathrm{s}$ (b) fütési sebesség $0,01^{\circ} \mathrm{C} / \mathrm{s}$

The above results clearly show the effects of temperature profile on the phase and morphology of $\mathrm{ZnS}$ nanoparticles. The low heating rate caused the formation of $\mathrm{WZ}$ type $\mathrm{ZnS}$ at $125^{\circ} \mathrm{C}$ then anisotropically grew by oriented attachment and finally formed rod like particle at $200^{\circ} \mathrm{C}$, while the particles generated at $200^{\circ} \mathrm{C}$ were isotropic ZB nanoparticles. Following these results, to investigate and clarify the stable structure for temperature between $100^{\circ} \mathrm{C}$ to $200^{\circ} \mathrm{C}$, we further modified the temperature profile and performed another experiment with the following conditions: the raw material solution was heated up to 100,125 , and $150^{\circ} \mathrm{C}$ with high heating rate $\left(500^{\circ} \mathrm{C} / \mathrm{sec}\right)$ and kept at each respective temperature for $1 \mathrm{~h}$. The results are shown in Fig. 3. At $100^{\circ} \mathrm{C}$, very thin $\mathrm{WZ} \mathrm{ZnS}$ nanorods (width $\sim 1.5 \mathrm{~nm}$ ) which resemble magic size nano wires recently reported by Den et.al. [29] were generated, whereas at $150^{\circ} \mathrm{C}$, isotropic $\mathrm{ZB}$ nanoparticles were obtained. At $125^{\circ} \mathrm{C}$, the product had a $2 \mathrm{~nm}$ diameter and appeared rather isotropic, but the phase was a mixture of $\mathrm{WZ}$ and $\mathrm{ZB}$ structures. From these results, it can be concluded that $\mathrm{ZB}$ was preferably generated above $125^{\circ} \mathrm{C}$, whereas $\mathrm{WZ}$ was favored below $125^{\circ} \mathrm{C}$. The difference in the crystal phase in the different generation temperatures could be the main reason for the temperature profile effects shown in Fig.1.
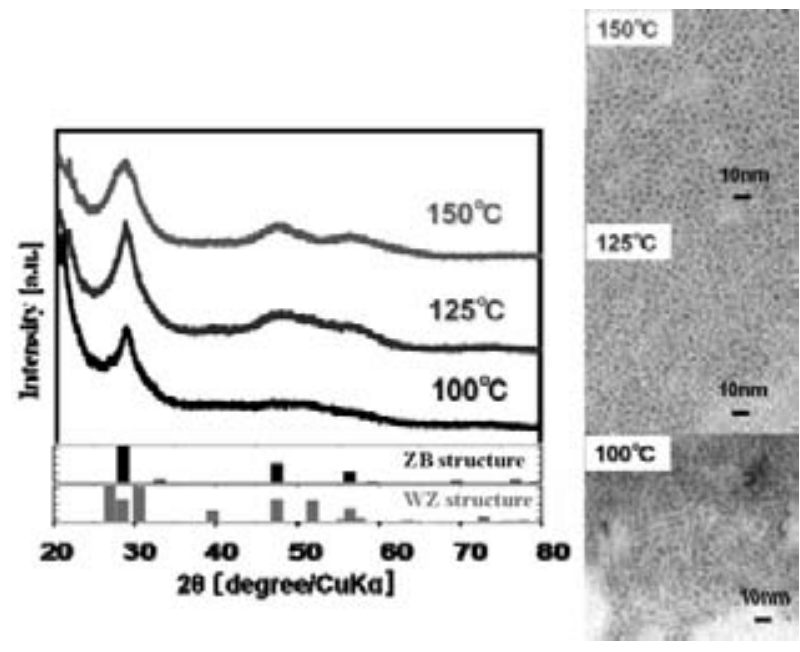

Fig. 3. XRD pattern and SEM images of ZnS nanoparticles 100,125 , and $150^{\circ} \mathrm{C}$
with high heating rate $\left(500^{\circ} \mathrm{C} / \mathrm{sec}\right)$
3. ábra $\mathrm{ZnS}$ nanorészecskék röntgen-diffraktogramjai és SEM felvételei 100,125 és
$150^{\circ} \mathrm{C}$-on, $500^{\circ} \mathrm{C} / \mathrm{s}$ fütési sebesség mellett

Finally, we tried to use the heating profile control to skip or enhance the critical temperature region for $\mathrm{WZ}$ particle. To enhance the $\mathrm{WZ}$ structure, the reaction solution was heated at a rate of $0.005^{\circ} \mathrm{C} / \mathrm{s}$ to reach $100^{\circ} \mathrm{C}$ and kept at this temperature. As shown in Fig. 4., the product had clear WZ phase and thicker $\mathrm{ZnS}$ nanorod with $3 \mathrm{~nm}$ width and $20 \mathrm{~nm}$ length. The width and length were much larger than those subjected to $1 \mathrm{~h}$ aging (Fig. 3.) regardless of the constant product yield, suggesting that ripening process proceed to enhance the $\mathrm{WZ}$ structure at this temperature. In contrary, the reaction mixture was heated at a rate of $500^{\circ} \mathrm{C} / \mathrm{sec}$ to reach $200^{\circ} \mathrm{C}$ (Fig. 1. profile-B) and kept at this temperature for $20 \mathrm{~s}$, then quenched to $75^{\circ} \mathrm{C}$ and kept for $24 \mathrm{~h}$ as shown in Fig. 5. This profile skips the temperature for WZ structure generation but aged at the temperature for WZ structure. The resultant particles had ZB structure with $3 \mathrm{~nm}$ that indicate isotropic ripening growth. The results show that ZB structure particles are favored over Ostwald ripening, and the initial heating profile actually determines the fate of the particles for this temperature. Consequently, temperature profile considering the critical temperature region is important 
to control the phase and morphology of $\mathrm{ZnS}$ nanocrystals by the current method.

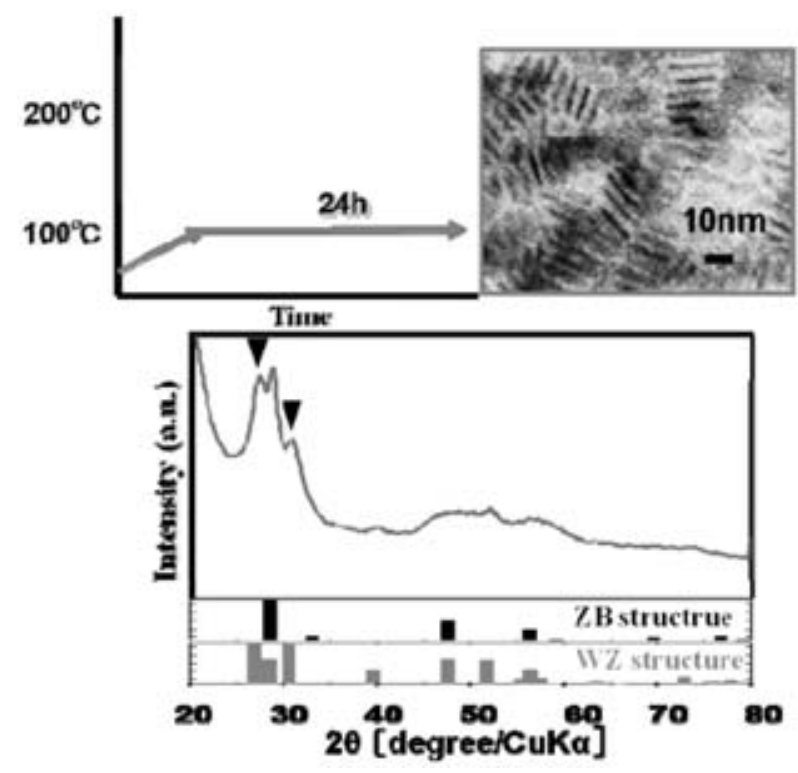

Fig. 4. XRD pattern and SEM images of ZnS nanoparticles at $100^{\circ} \mathrm{C} 24 \mathrm{~h}$ (heating rate: $0.005^{\circ} \mathrm{C} / \mathrm{sec}$ )

4. ábra ZnS nanorészecskék röntgen-diffraktogramjai és SEM felvételei $100^{\circ} \mathrm{C}$-on, 24 órás kezeléskor, $0,005^{\circ} \mathrm{C} / \mathrm{s}$ fütési sebesség mellett

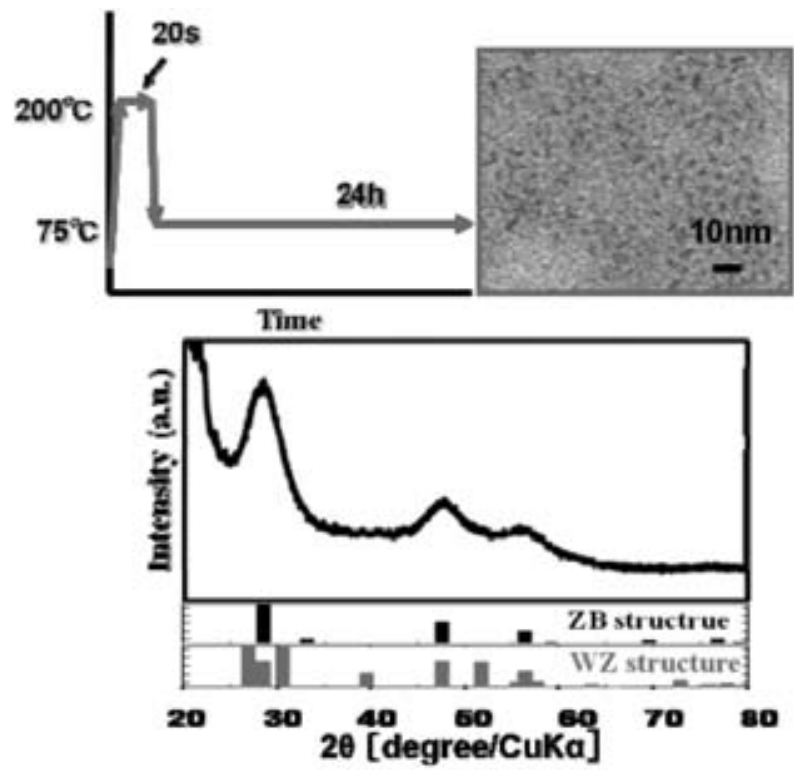

Fig. 5. XRD pattern and SEM images of ZnS nanoparticles at $75^{\circ} \mathrm{C}, 24 \mathrm{~h}$ (heating rate: $500^{\circ} \mathrm{C} / \mathrm{sec}$ to $200^{\circ} \mathrm{C}$ )

5. ábra ZnS nanorészecskék röntgen-diffraktogramjai és SEM felvételei $75^{\circ} \mathrm{C}$-on, 24 órás kezeléskor, $500^{\circ} \mathrm{C} / \mathrm{s}$ fütési sebesség mellett

\section{Conclusion}

In this study, ZnS nanocrystals were synthesized from identical raw material solutions, and the effects of temperature profile on the resultant phase and morphology of $\mathrm{ZnS}$ nanocrystals were investigated. It was possible to obtain a rod like $\mathrm{ZnS}$ particles by slow heating $\left(0.01^{\circ} \mathrm{C} / \mathrm{s}\right)$ up to $200^{\circ} \mathrm{C}$, whereas a fast heating rate $\left(500^{\circ} \mathrm{C} / \mathrm{s}\right)$ formed spherical nanoparticles. Particle generation and growth during those processes revealed that wurtzite (WZ) $\mathrm{ZnS}$ nanoparticles were generated below $125^{\circ} \mathrm{C}$ for the slow heating rate and undergo oriented attachment to generate rod like particles, whereas the fast heating rate generates zinc blende (ZB) type $\mathrm{ZnS}$ nanoparticles after reaching $200^{\circ} \mathrm{C}$, showing the clear effects of particle generation temperature on the crystal phase. A series of fast heating rates up to various temperatures revealed the effects of generation temperature and showed that the marginal line for $\mathrm{ZB}$ type and $\mathrm{WZ}$ type particle generation was around $125^{\circ} \mathrm{C}$. Further experiment on aging for a long period of time for $\mathrm{WZ}$ generation region enhanced the $\mathrm{WZ}$ structure to give thick rod like particles, whereas skipping $\mathrm{WZ}$ generation region by rapid heating presented ripening of spherical $\mathrm{ZB}$ nanoparticles at low temperature aging. Consequently, the series of simple experiments successfully showed the importance of temperature profile for shape and phase control even in cases of using the same starting solution. In our additional experiments, we also tried to control the phase and shape of $\mathrm{ZnSe}$ nanocrystals via temperature profile by using microreactor which made it possible to realize more precise heating profile control. The results will be reported in our next publication.

\section{Acknowledgment}

This work is supported by the Core Research for Evolutional Science and Technology (CREST) program of the Japan Science and Technology Corporation (JST).

\section{References}

[1] J. Park - J. Joo - S.G. Kwon - Y. Jang - T. Hyeon: Angew. Chem. Int. Ed. 46 (2007) 4630-4660 and references therein.

[2] Y. Yin - A. P. Alivisatos: Nature, 437 (2005) 664-670 and references therein.

[3] E. E. Finney - R.G. Fink: J. Colloid Interface Sci., 317 (2008), 351-374.

[4] X. G. Peng - J. Wickham - P. Alivisatos: J. Am. Chem. Soc. 120 (1998) 5343-5344.

[5] J. van Embden - J. E. Sader - M. Davidson - P. Mulvaney: J. Phys. Chem. C, 113 (2009) 16342-16355.

[6] J. Y. Rempel - M.G. Bawendi - K. F. Jensen: J. Am Chem. Soc., 131,(2009) 4479-4489.

[7] K. Nam - J. Shim - D.W. Han - H. S. Kwon - Y. M. Kang - Y. Li - H. J. Song - W. S. Seo - J. T. Park: Chem. Mater, 22 (2010) 4446-4454.

[8] D. J. Norris - A. L. Efros - S. C. Erwin: Science, 319 (2008) 1776.

[9] H. G. Bagaria - G. B. Thompson - M. Shamsuzzoha - D. E. Nikles - D.T. Johnson: Journal of Applied Physics 101 (2007) 104313.

[10] P.D.Cozzoli- L.Manna - M.L. Curri - S. Kudera - C. Giannini - M. Striccoli - A. Agostiano: Chem. Mater., 17 (2005) 1296-1306.

[11] Y. Yang - O. Chen - A. Angerhofer - Y. C. Cao: J. Am. Chem. Soc., 130 (2008) 15649-15661.

[12] C. Lizandara-Pueyo - M. W. E. van den Berg - A. De Toni - T. Goes - S. Polarz: J. Am. Chem. Soc., 130 (2008) 16601-16610.

[13] L. Manna - E.C. Scher - A.P. Alivisatos: J. Am. Chem. Soc., 122 (2000) $12700-12706$.

[14] V. F. Puntes - D. Zanchet, - C. K. Erdonmez - A. P. Alivisatos: J. Am. Chem. Soc., 124 (2002) 12874-12880.

[16] J. Joo - J. M. Pietryga - J. A. McGuire - S.H. Jeon - D. J. Williams - H.L. Wang - V. I. Klimov: J. Am. Chem. Soc. 131 (2009) 10620-10628.

[17] C. G. Lee - Y. Nakamura - H. Nakamura - M. Uehara - H. Maeda: (in submitting).

[18] H. Nakamura - A. Tashiro - Y. Yamaguchi - M. Miyazaki - T. Watari - H. Shimizu - H.Maeda: Lab Chip, 4 (2004), 237-240.

[19] X. S. Fang - T. Zhai - U. K. Gautam - L. Li - L. Wua - Y. Bando - D. Golberg: Prog. Mater. Sci. 56 (2011) 175-287.

[20] C. Y. Yeh - Z.W. Lu - S. Froyen - A. Zunger: Phys Rev B 46 (1992) $10086-$ 10097. 
[21]T. Akiyama - K. Sano - K. Nakamura - T. Ito: Jpn J Appl Phy, 46 (2007)1783-1787.

[22] e.g., Y. Li - X. Li - C. Yang - Y. Li: J. Phys. Chem. B, 108 (2004) 1600216011.

[23] L. Jiang - M. Yang - S. Zhu - G. Pang - S. Feng: J. Phys. Chem. C, 112 (2008) 15281-15284.

[24] S. Biswas - S. Kar: Nanotech. 19 (2008) 045710.

[25] H. Tong - Y. Zhu - L. Yang - L. Li - L. Zhang - J. Chang - L. An - S. Wang: J. Phys. Chem. C, 111 (2007) 3893-3900.

[26] J. Joo - H. Na - T. Yu - J. Yu - Y. Kim - F. Wu - J. Zhang - T. Hyeon: J. Am. Chem. Soc. 125 (2003) 11100-11105.

[27] J. Zhang - F. Huang - Z. Lin: Nanoscale, 2 (2010) 18-34.

[28] Z. Deng - H. Yan - Y. Liu: Angew. Chem. Int. Ed., 49 (2010) 8695 -8698.

Ref.: http://dx.doi.org/10.14382/epitoanyag-jsbcm.2011.9

Chan Gi Lee - Yusuke Nakamura - Hiroyuki Nakamura - Masato

Uehara - Hideaki Maeda: Controlling the structure and morphology of ZnS nanoparticles by manipulating the temperature profile. Építőanyag, 63. évf. 3-4. szám (2011), 52-56. p.
Cink-szulfid nanorészecskék szerkezetének és morfológiájának szabályozása a hőmérsékletprofil változtatásával

Módszert javaslunk reakciók idốbeli lefutásának szabályozására a reakciókörülmények szigorú idôbeli beállításával. ZnS nanorészecskéket tartalmazó, azonos összetételú oldatokban, megfelelố hômérsékleten beindított szakaszos reakciók esetén tanulmányoztuk a különbözó hômérsékletprofilok hatását a lejátszódó folyamatokra. A ZnS kiindulási anyagot két különbözô fûtési sebesség $\left(0,01^{\circ} \mathrm{C} / \mathrm{s}\right.$ és $\left.500^{\circ} \mathrm{C} / \mathrm{s}\right)$ mellett melegítettük fel a kivánt hômérsékletre. Nagy fútési sebességnél cink-elegyfázisú (ZB), gömbszerú nanorészcskékbôl álló anyagot kaptunk $125^{\circ} \mathrm{C}$ felett. Kis hútési sebességnél würzitet tartalmazó (WZ) ZnS nanorudak keletkeztek. Megállapítottuk továbbá, hogy a végtermékek fázisviszonyait a részecskék elôállításakor alkalmazott kiindulási hômérséklet határozza meg.

Kulcsszavak: fázisösszetétel és morfológia szabályozása, hômérsékletprofil, ZnS nanorészecske

\section{FOLYÓIRATSZEMLE}

\section{Isoliertechnik}

\section{1. szeptember}

A lap a Bundesfachgruppe WKSM im Zentralverband des Deutschen Baugewerbes, a Verband Österreicher Dämmunternehmungen és a Verband Schweizerischer Isolierfirmen hivatalos kiadványa.

- Új nevek szigeteléstechnikai nagyvállalatoknál, a SaintGobain Isover G+H AG-nél, az AGI auf der Habsburg-nál, a FLIR System in Frankfurt-nál, a Knauf Verwaltungsgesellschaft-nál, a Gesamtverband Dämmstoffindustrie-nál

- Aktuális hírek a Korff, a Lindner, az Isover, a Dr. Starck \& Co. GmbH, az Armacell, a Rockwool és Kaefer cégektôl

- ISO'12, Európa legnagyobb szigeteléstechnikai szakkiállítása KöInben, 2012. május 10-11-én

Cikkek:

- Hôvédelem a jövôben

- Új üzemi struktúra a Rockwool-nál

- A jövố energiatakarékos házai

- Zajcsökkentés és szigetelés az RWE Emslandi gázerômúvében

- Kirajzolódik a változás az energiaszektorban

- Brüsszeli visszhangok a német energiafordulatról

- Elasztomerhabok ragasztása - kontaktragasztók

- Párafékezô anyag, vagy párazáró anyag a hidegtechnológiai szigetelésben

- Építési szerzôdések - illegális gyakorlat az alvállalkozók alkalmazásában

- Változó hômérsékletũ berendezések szigetelése

- Csōátvezetések szakszerú elhatárolása elasztomerhabokkal - tûzvédelem

- Ipari hôszigetelésrôl - új ISOVER weboldal

- A szakipar esélyei - a fútés egyre drágább

- 2 az egyben - Arma-Chek Silver az Armacell-tôl

- RAL - új minôségtanúsítvány a múanyaghabokra

- Szerelt füstcsatornák - építési tũzvédelem

- Új F90 szigetelés sprinkler berendezésekre a Rockwool-tól

- Polyrock - hangelnyelô, függesztett álmennyezet a Rockwooltól

- Teremakusztikai megoldások nagy terekre - Hanno-Tect

- Kaiflex termékek UL tanúsítása

\section{Glass International}

2011. március, pp. 11-14.

\section{Stuart Hakes: Hogyan javítja az úrkompoknál alkalmazott bevonási technológia az üvegolvasztó kemencék bolto- zatának emissziós tényezőjét}

Az üvegolvasztó kemencék energia-megtakarításának új módszerét mutatja be a cikk szerzôje, mely a közelmúltban nyert ipari alkalmazást.

Egy licencátadási program keretében lehetôvé vált, hogy a NASA által kifejlesztett, és az úrkompok külsô szigeteléséhez nano-részecskéket felhasználó bevonatokat az üvegipar is átvehesse. Ehhez elôzően olyan kötôrendszereket kellett kifejleszteni, mellyel a bevonat a kemence túzálló falazatának az üveggel nem érintkezố felületére felhordható. A bevonat igazi haszna, hogy emissziós tényezôje magas hômérsékleten megközelíti az elméleti (fekete test) értéket. Míg a kemence túzálló falazatának emissziós tényezôje a 0,4-0,6 közötti tartományban van az olvasztás hômérsékletén, addig az Emisshield márkanevú bevonaté kb. 0,9. Ez azt jelenti, hogy a bevonat által elnyelt hố mintegy 90\%-át visszasugározza a hidegebb üvegolvadékra.

A bevonatot kereskedelmileg 2006-ban vezette be a NARCO a FIC (UK) céggel együttmúködésben, és mára már számos, elsôsorban multinacionális cég vette alkalmazásba. A bevonat viszonylag egyszerūen, felszórással (szórópisztollyal) hordható fel a hideg kemencék belsố felületére. Meg kell jegyezni, hogy a bevonatot nem célszerú öntött AZS blokkokra alkalmazni, mivel azok magas hômérsékleten üveges fázist „izzadnak” ki magukból, ami jelentôsen csökkenti a bevonat hatékonyságát. A cikk szerint 28 alkalmazás fele un. „oxy-fuel”, míg másik fele hagyományos gáztüzelésú kemencénél került bevezetésre különbözô üvegtípusoknál: a palacküvegtôl a vízüvegen át a bórtartalmú üvegig.

Az Emisshield szélesebb körú kipróbálása újabban kiterjed a munkakádak, fútött csatornák és a gyártó szerszámok területére is.

A bevonat komplex gazdasági és környezeti előnyökkel bír. A cikk szerinti 28 gyakorlati alkalmazás és több éves üzemeltetés után elmondható, hogy $10 \%$ földgáz-megtakarítás is elérhetô a kemencék méretétốl függôen. Emellett természetesen arányosan csökken a kemencék $\mathrm{CO}_{2}, \mathrm{SO}_{x}$ és $\mathrm{NO}_{x}$ kibocsátása is.

Lipták György 